\title{
Snowfall series of Turin, 1784-1992: climatological analysis and action on structures
}

\author{
EZIO LEPORATI \\ Dipartimento di Ingegneria Strutturale, Politecnico di Tórino, Italy \\ LUCA MERCALLI \\ Ente di Sviluppo Agricolo del Piemonte, V. Petrarca 44, I-10126 Tórino; Comitato Glaciologico Italiano, Tórino, Italy
}

\begin{abstract}
The snowfall series of Turin, northwest Italy, is one of the longest available for Europe, with daily observations starting in 1784 and continuous since 1788. The unpublished 207 years data set was carefully obtained from original manuscripts and filed on magnetic media. Mean yearly snowfall amount is $48.9 \mathrm{~cm}$ showing a high interannual variability (variation coefficient $79 \%$ ), with about seven snow days from October through April; the maximum amount was measured in winter $1784-85(233 \mathrm{~cm})$, followed by $1808-9$ with $163 \mathrm{~cm}$. Maximum daily amount was on 4 December 1844 with $64 \mathrm{~cm}$. During the whole period a negative trend is exhibited, increasing in the years following 1890 . This pattern is confirmed by the Mann-Kendall test. The change derives from regional climate rather than expansion of the urban area. Return periods of yearly maximum snow loads are calculated in order to contribute to the definition of new values for structural design. A case study of heavy snowfall in January 1987 is examined.
\end{abstract}

\section{INTRODUCTION}

Turin lies at $240 \mathrm{~m}$ elevation in the west zone of the Po plain $\left(45^{\circ} 03^{\prime} \mathrm{N}, 7^{\circ} 40^{\prime} \mathrm{E}\right), 15 \mathrm{~km}$ from the alpine reliefs of Susa Valley. The urban area is about $130 \mathrm{~km}^{2}$, extending mostly northwest along the Po river. The first descriptive observations concerning snowfall date back to 1675 , while daily measurements began in 1784. The numerous manuscripts that have been accumulated during two centuries, at times dispersed in different places, have been carefully analysed; the numerical data have been turned into standard units and filed on computer media, for the first time allowing analysis of the most ancient snow series in Europe.

\section{DATA SOURGES AND PROGESSING}

Between 1675 and 1681 the Royal Italian mathematician, Donato Rossetti made a study of the shape of snow crystals, publishing the results in a booklet entitled $L a$ Figura della neve (The shape of snow), and highlighting the hexagonal structure of crystals. Between 1682 and 1721 sporadic snowfall descriptions are reported in F.L. Sloeri's Diary (Rebaudengo, 1969) and later resumed (1753-93) by Count Ignazio Somis. Quantitative measurements of snowfall began with G. D. Beraudo (1785) who founded the first meteorological observatory in the town centre in 1780 . Unfortunately some data have been lost and only daily snow data, for the exceptional winter $1784-85$, are left. Since 1788 with the foundation of the
Observatory of the Royal Academy of Sciences directed by A. M. Vassalli-Eandi $(1808,1810)$ daily measurements were regularly handwritten in registers till 1865, when the Observatory moved to Palazzo Madama. There measurements were made till 1919. From then observations were performed at the Physics Institute of the Royal University (1930-43). Since 1928 a thermopluviometric station of Ufficio Idrografico del Po has operated. All of the above meteorological stations are located in the central area of the town, in comparable conditions, so that the whole series of daily snowfall presents only slight inhomogeneities for climatological analysis. When possible, data were checked with newspaper information.

\section{CHARACTERISTICS OF SNOWFALL IN TURIN}

\section{Meteorological patterns of snowfall}

Meteorological patterns influencing snowfall in the Turin region can be categorised as:

Western and northwestern: characterised by the passage of Atlantic fronts, generally fast and greatly influenced by their passing over the Alps. They produce wet snowfall of light or moderate intensity $(1-15 \mathrm{~cm})$,

Northern and eastern: eruptions of cold continental air combined with weak intensity fronts that usually bring a small quantity of light snow $(1-5 \mathrm{~cm})$ and

Southern: with respect to snowfalls, the most active 
circulation, formed by moist air arriving from the Mediterranean sea during cyclonic events over Genoa Gulf. Produces hard and protracted snowfalls $(>20 \mathrm{~cm}, 2-5 \mathrm{~d})$ that are wet because of temperatures close to $0^{\circ} \mathrm{C}$, showing high values of water equivalent.

\section{STATISTICAL CHARACTERISTICS}

\section{New snowfall depth}

We have analysed the depth of daily new snowfall generally measured around $0800 \mathrm{~h}$ or, in the case of brief precipitation, during the day. For the period 1784 1848 French measure units have been converted to $\mathrm{cm}$ using the relations: 1 inch $=2.7070 \mathrm{~cm}$ and 1 line $=$ $0.2256 \mathrm{~cm}$ (Vassalli-Eandi, 1806). The series starts in the last months of 1787 and continues till 1992. Adding the winter of 178485 the data set amounts to 207 years. The snowfall for 206 snow seasons (October through April)

Table 1. Turin, $240 \mathrm{~m}$. Yearly (October-April) snowfall amounts (cm). Period 1784 85; 1787-88/1991-92

$\begin{array}{lclc}\text { Mean } & 48.9 & \text { Percentile } 0.1 & 7 \\ \text { Standard deviation } & 38.7 & \text { Percentile } 0.2 & 15 \\ \begin{array}{lcc}\text { Coefficient of } \\ \quad \text { variation }\end{array} & 0.79=79 \% & \text { Percentile } 0.5 & 42.5 \\ \begin{array}{l}\text { Minimum value } \\ \text { Maximum value }\end{array} & 0 & & \\ & 233(1784-85) & \text { Percentile } 0.8 & 75 \\ & & & \end{array}$

exhibit parameters shown in Table 1.

Mean yearly snowfall amount shows considerable interannual variability as the high value of the coefficient of variation indicates, one year out of ten exhibiting less than $7 \mathrm{~cm}$ or more than $98 \mathrm{~cm}$, while one year out of five exhibits less than $15 \mathrm{~cm}$ or more than $75 \mathrm{~cm}$. A few winters were without snow $(1.9 \%$ of the sample), while the winter of 178485 , with $233 \mathrm{~cm}$ of snow was considered exceptional and for this reason the observer

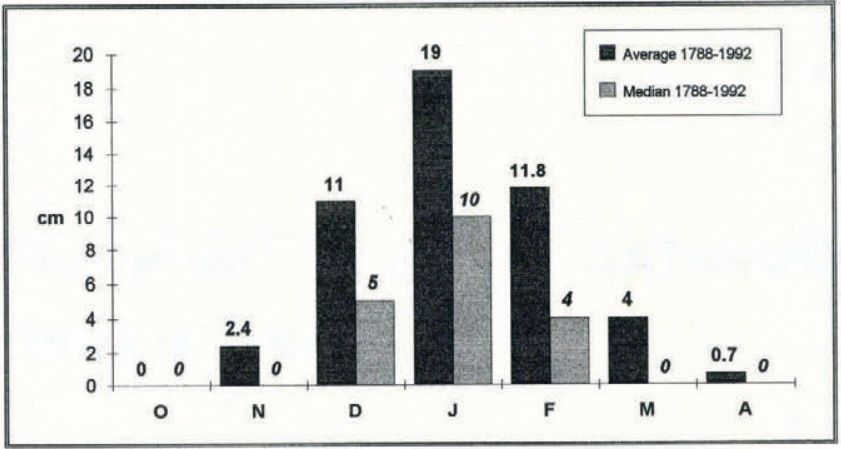

Fig. 1. Turin. Histogram of mean monthly snowfall amounts (cm) (period 1784 85; 1788-1992).

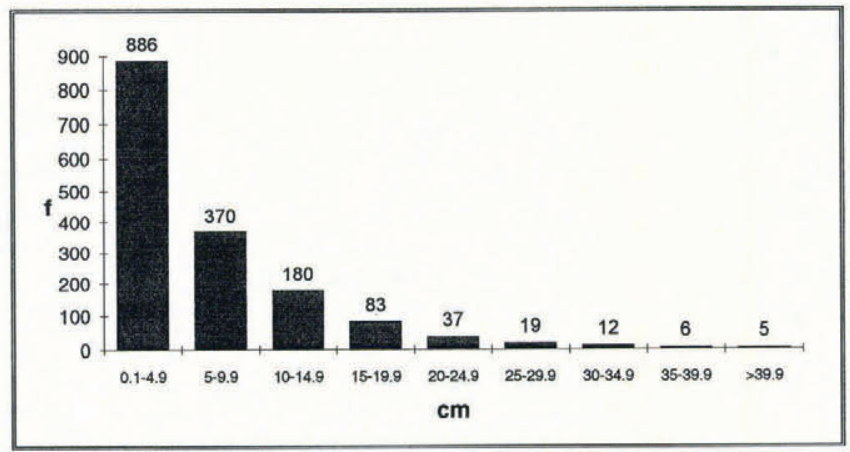

Fig. 2. Turin, $240 \mathrm{~m}$. Histogram of frequencies of daily snowfall amount (cm), period 1788-1992.

Beraudo drew up a special table. Such values were never again attained, the value immediately below this being $163 \mathrm{~cm}$ in the winter of 1808-9. Statistical parameters of monthly snowfall amount are reported in Table 2 . The distribution of snow heights follows the thermic course, with maximum in January coinciding with the mean temperature minimum (Fig. 1). Coefficient of variation of monthly snowfall amounts is in all these months higher than $100 \%$. January and December show greater regularity than autumn and spring months, in which snowfalls are rare. Snow in October is unusual (only two cases, in 1920 and in 1979), while in April it is more frequent because of the continuing winter meteorological

Table 2. Turin, $240 \mathrm{~m}$. Monthly snowfall amounts (cm). Period 1784 85; 1788/1992

\begin{tabular}{|c|c|c|c|c|c|c|c|c|c|c|}
\hline Month & Mean & Std dev & CVar $\%$ & Min & $\operatorname{Max}$ & $P 0.1$ & $P 0.2$ & $P 0.5$ & $P 0.8$ & P 0.9 \\
\hline Oct & 0 & $*$ & $*$ & 0 & $6(1979)$ & 0 & 0 & 0 & 0 & 0 \\
\hline Nov & 2.4 & 6.6 & 275 & 0 & 53 (1895) & 0 & 0 & 0 & 2 & 8 \\
\hline Dec & 11.0 & 17.4 & 158 & 0 & $\begin{array}{r}129 \quad(1808, \\
1844)\end{array}$ & 0 & 0 & 5 & 18 & 28 \\
\hline Jan & 19.0 & 22.9 & 121 & 0 & $122(1805)$ & 0 & 1 & 10 & 36 & 52 \\
\hline Feb & 11.8 & 19.0 & 161 & 0 & 115 (1888) & 0 & 0 & 4 & 19 & 36 \\
\hline Mar & 4.0 & 9.2 & 230 & 0 & $56(1796)$ & 0 & 0 & 0 & 5 & 12 \\
\hline Apr & 0.7 & 3.0 & 429 & 0 & $29(1834)$ & 0 & 0 & 0 & 0 & 0 \\
\hline
\end{tabular}

* For Mean $=0$, STD and CVar cannot be calculated. 
Table 3. Turin, $240 \mathrm{~m}$. Frequencies of daily snowfall amounts. Period 1788-1992

Class interval Frequency $\begin{gathered}\text { Cumulative Relative Relative } \\ \text { frequency frequency cumulative } \\ \text { frequency }\end{gathered}$

$\mathrm{cm}$

$\begin{array}{crrrr}0.1-4.9 & 886 & 886 & 0.554 & 0.554 \\ 5.0-9.9 & 370 & 1256 & 0.232 & 0.786 \\ 10.0-14.9 & 180 & 1436 & 0.113 & 0.898 \\ 15.0-19.9 & 83 & 1519 & 0.052 & 0.950 \\ 20.0-24.9 & 37 & 1556 & 0.023 & 0.973 \\ 25.0-29.9 & 19 & 1575 & 0.012 & 0.985 \\ 30.0-34.9 & 12 & 1587 & 0.008 & 0.993 \\ 35.0-39.9 & 6 & 1593 & 0.004 & 0.996 \\ >39.9 & 5 & 1598 & 0.003 & 1.000 \\ & & & & \end{array}$

circulation, with 18 cases $(8.7 \%$ of the sample). There are zero values in every month and in many cases.

The bar graph of frequencies of daily snowfall amounts (1598d) shows a sharp prevalance $(55 \%)$ of feeble intensity events up to $5 \mathrm{~cm}$ (Table 3, Fig. 2). Daily snowfalls higher than $30 \mathrm{~cm} \mathrm{(23)} \mathrm{are} \mathrm{only} 1.5 \%$ of the total number of events, showing a maximum of $64 \mathrm{~cm}$ on 4 December 1844. If we consider consecutive days of snowfall we find a maximum of $85 \mathrm{~cm}$ occurred in 1808 , from 23 to 25 December.

Table 4. Turin, $240 \mathrm{~m}$. Yearly (October-April) number of snow days. Period 1787-8/1991-92

$\begin{array}{llll}\text { Average } & 7.9 & \text { Percentile } 0.1 & 2 \\ \text { Standard deviation } & 5.0 & \text { Percentile } 0.2 & 4 \\ \begin{array}{l}\text { Coefficient of } \\ \quad \text { variation }\end{array} & 0.64=64 \% & \text { Percentile } 0.5 & 7 \\ \begin{array}{l}\text { Minimum value } \\ \text { Maximum value }\end{array} & 0 & \text { Percentile } 0.8 & 11 \\ & 30(1837-38) & \text { Percentile } 0.9 & 14\end{array}$

\section{Snow days}

In this work we have considered snow days as those with at least $1 \mathrm{~cm}$ of new snowfall, excluding days showing a lower value of snow on the ground. The series of snow days in Turin during the period 1788-1992 exhibits the statistical parameters of Table 4 .

Like snowfall amounts, the number of snow days is also subject to considerable interannual variability (coefficient of variation $64 \%$ ), with a median value of 7. One year out of ten may have less than two or more than 14 snowfall days. For agricultural implications it is interesting to analyse the main cases of early or late snowfalls (Table 5).
Table 5. Turin, $240 \mathrm{~m}$

\begin{tabular}{cccc}
\multicolumn{2}{c}{ Late snowfalls } & Early snowfalls \\
Date & Depth & Date & Depth \\
& & \\
& $\mathrm{cm}$ & $\mathrm{cm}$
\end{tabular}

$\begin{array}{lrrr}25 \text { April } 1972 & 3 & 27 \text { October } 1979 & 6 \\ 24 \text { April } 1883 & 2 & 31 \text { October } 1920 & 2 \\ 21 \text { April } 1838 & 7 & \text { 1 November } 1920 & 12 \\ 20 \text { April } 1838 & 1 & \text { 2 November } 1920 & 30 \\ 20 \text { April 1954 } & 12 & \text { 2 November } 1919 & 2 \\ 18 \text { April 1991 } & 2 & \text { 3 November 1880 } & 2 \\ 17 \text { April 1991 } & 6 & \text { 7 November } 1858 & 15\end{array}$

The extreme dates with at least $1 \mathrm{~cm}$ snowfall recorded in a $207 \mathrm{yr}$ period range from 25 April 1972 to 27 October 1979. The latest date in which a snow event has been reported for Turin was 1 May 1714, when Soleri reported a snowfall from 2000 to $2400 \mathrm{~h}$. The same observer reported a snowfall on 27 April 1713.

Damage due to autumn snowfalls is rare. Effects of spring snowfalls are greater because mechanical damage on arboreal vegetation already covered with leaves combines with physiological damage of vegetative organs caused by the low temperature around $0^{\circ} \mathrm{C}$. The event of 17-18 April 1991 was particularly hard as the total snowfall amount reached $8 \mathrm{~cm}$ in the town and over $20 \mathrm{~cm}$ in the hilly neighbourhood.

\section{SNOWFALL BEHAVIOUR THROUGH TWO CENTURIES}

\section{Inhomogeneities introduced by urbanisation}

Analysis of the snowfall amount time series of Turin cannot leave aside considerations of possible inhomogeneities introduced by the increase of urbanisation during the last two centuries. Turin's population has grown from $43.87 \times 10^{3}$ in 1702 to $1.115 \times 10^{6}$ in 1981 . For most towns, due to heat-island effects in winter, temperature is higher inside than out. This fact may have influenced the evolution of snowfall amount, causing a reduction in the period following 1950. This variation, strictly connected with urban climate, is negligible in the context of the climatological analysis, for the following reasons:

- The geographical conformation of the town of Turin, bounded to southeast by the River Po and by the hilly ground (up to $700 \mathrm{~m}$ ) has stopped urban expansion in those directions. The meteorological observatories are placed in this zone, coinciding with the historical centre of the town. Therefore they have undergone little change (as time passed) of their microclimate. They have also always been in an urban situation.

- Comparing the snowfall series of Turin with those of 


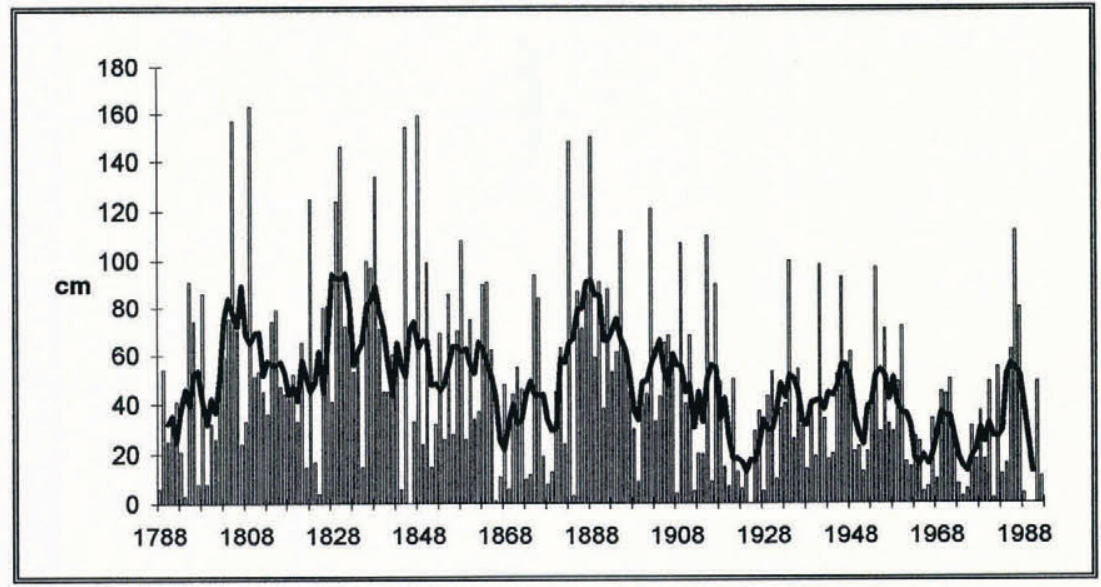

Fig. 3. Turin, $240 \mathrm{~m}$. Yearly (October-April) snowfall amount and 5 yr moving mean, period 1787-88/1991-92. Series maximum value is $233 \mathrm{~cm}$ (1784 85), here not indicated as separated from continued measurements.

the town of Bra (290 m, period 1862-1991 (Brizio and Mercalli, 1991)) and Cuneo (530 m, period 1877-1990 (Biancotti and others, 1991)) indicates that the snowfall amount decrease is a common characteristic after 1915, not depending on local conditions. Both are small towns with no considerable urbanisation.

\section{Snowfall amount time-series analysis}

We applied a 5 yr moving mean to the graph in Figure 3 of winter snowfall amount (October through April), to smooth interannual variations. The graph shows a period of high snowfall from 1800 to 1860 . A decrease followed around 1870, and then an increase between 1880 and 1890. After 1900 a decrease phase began, with a minimum in the decade 1920 to 1930 , a weak increase between 1940 and 1950, a new lower-than-normal period between 1960 and 1975, then a higher-than-normal period between 1981 and 1987. The last years of the series show low values with the only case of two consecutive years without snow (1988-89 and 1989-90). A negative trend is confirmed for this data by the nonparametric Mann-Kendall test (Giuffrida and Conte, 1989).
Figure 4 plots the number of snow days for the record period. The $5 \mathrm{yr}$ moving mean is plotted. The number of days measuring at least $1 \mathrm{~cm}$ snowfall shows a decrease through two centuries, with maximum from 1800 to 1860 and minimum in the decade 1920 to 1930 . A weak negative trend is confirmed for these data also, by the Mann-Kendall test.

Interesting historic data also confirm that there was more snow (duration and amount) during the 19th century. The Savoy Royal Family moved by sledge from the Royal Palace to Valentino park, as noticed by Soleri in January 1718 and 1719. Soleri also reported snow piles remaining in shady yards on 22 May 1716.

\section{SNOW LOADS ON STRUCTURES}

Intensity and distribution of snow loads on roofs, $q^{*}$, depends on geographical, physical and geometrical parameters. Among these are latitude, climate, altitude, type of building, pitch slope and roofings, roof structure, temperature and wind. To obtain the load, $q^{*}$, on the roof of a building, one multiplies the load, $q$, acting on the ground (and here experimentally determinable) by the

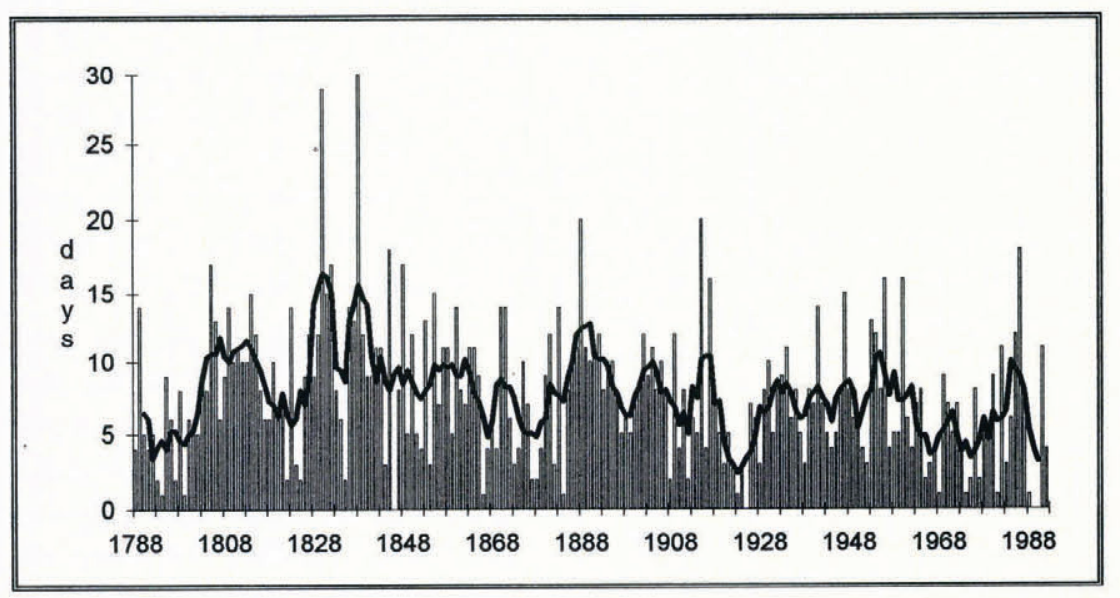

Fig. 4. Turin. Yearly (October-April) number of snowy days (with at least $1 \mathrm{~cm}$ ) and 5 yr moving mean (period 1787-88/199192). 
shape coefficient $\mu$ by the exposure coefficient $C_{\mathrm{e}}$ and by the thermic coefficient $C_{\mathrm{t}}$ as follows:

$$
q^{*}=\mu \cdot C_{\mathrm{e}} \cdot C_{\mathrm{t}} \cdot q
$$

Values of these coefficients are reported in the national technical rules and in international notices. Values of $q$ are generally stated for geographical areas as a function of elevation of the location. Italian technical regulations at present in force (Ministero dei Lavori Pubblici, 1982a, b) provide a snow load at the ground, $q$ for the Piedmont district (with Turin as the regional capital) and for other districts in northern Italy, of:

$$
\begin{array}{r}
q=0.90 \mathrm{kN} \mathrm{m}^{-2} \quad \text { for } A \leq 300 \mathrm{~m} \\
q=\left[0.90+\frac{1.5}{1000}(A-300)\right] \mathrm{kN} \mathrm{m}^{-2} \\
\text { for } A>300 \mathrm{~m}
\end{array}
$$

$A$ is the elevation a.s.l. expressed in m. Particularly, as Turin lies at $240 \mathrm{~m}, q=0.9 \mathrm{kN} \mathrm{m}^{-2}$. These rules are unfavourable for safety as is confirmed almost every year by damage to roofs, large industrial sheds and other structures. At present the Comitato di Studio per i Carichi e Sovraccarichi del Ministero dei Lavori Pubblici-1a Sezione, is preparing new proposals for snow loads, deduced by several studies carried out at different Italian locations with observation periods of about $50 \mathrm{yr}$. These proposals appear much safer than rules currently in force. For instance, in the Piedmont area, load values on the ground for return period $T_{0}=200 \mathrm{yr}$ are given by the following relations:

$$
\begin{aligned}
q_{T_{0=200}}= & 1.60 \mathrm{kNm}^{-2} \\
& \text { for } A<200 \mathrm{~m} \\
q_{T_{0=200}}= & 1.60+3(A-200) / 1000 \mathrm{kN} \mathrm{m}^{-2} \\
& \text { for } 200 \mathrm{~m}<A<750 \mathrm{~m} \\
q_{T_{0=200}}= & 3.25+8.5(A-750) / 1000 \mathrm{kN} \mathrm{m}^{-2} \\
& \text { for } A>750 \mathrm{~m}
\end{aligned}
$$

Data obtained for this work cover over $200 \mathrm{yr}$ of observations, the longest we have found in specific references, can contribute to check Equation (3) for the Turin area. Note that Equation (3) gives a value of $q=1.720 \mathrm{kN} \mathrm{m}^{-2}$ for $A=240 \mathrm{~m}$, the elevation of Turin.

\section{Maximum snowfall depth in Turin}

Yearly maximum new snowfall depths, $h_{1}$, occurring during one or more consecutive days, (or rather, for the years in which it happens, the snowfall amount of consecutive days with at least $1 \mathrm{~cm}$ of new snow), have been ranked in order of magnitude, so that

$$
\left(h_{1}\right)_{1} \leq\left(h_{1}\right)_{2} \leq \ldots\left(h_{1}\right)_{m} \leq \ldots\left(h_{1}\right)_{h} .
$$

Each variate $\left(h_{1}\right)_{m}$ is assigned the Weibull probability index equal to:

$$
P_{m}=\frac{m}{n+1}
$$

and single points, coordinate $\left[P_{m},\left(h_{1}\right)_{m}\right]$ were plotted on a Gumbel diagram (Fig. 5). This graph shows that yearly maximum new snowfall depths fit an extreme value type 1 distribution (El), with the following statistical parameters:

$$
\begin{array}{lrl}
\text { average } & \bar{h}_{1}=0.213 \mathrm{~m} \\
\text { standard deviation } & \sigma_{\mathrm{h}_{1}}=0.173 \mathrm{~m} \\
\text { coefficient of variation } & c_{\mathrm{h}_{1}}=0.812=81.2 \% \\
\text { minimum } & \left(h_{1}\right)_{\min }=0 \mathrm{~m}(\text { years } 1866, \\
& & 1923,1989) \\
\text { maximum } & \left(h_{1}\right)_{\max }=0.850 \mathrm{~m} \text { (year } 18 \\
\text { fractile } 0.95 & \left(h_{1}\right)_{0.95}=0.536 \mathrm{~m}
\end{array}
$$

For an E1 distribution, argumental values associated with return periods $T_{0}$ (years) are determinable following the relations (Leporati, 1983):

$$
\begin{aligned}
h_{T_{0}} & =\bar{h}_{1}\left(1+K_{T_{0}} c_{q_{1}}\right) \\
K_{T_{0}} & =\frac{-\ln \left[-\ln \left(1-\frac{1}{T_{0}}\right)\right]-0.5772}{1.2825} .
\end{aligned}
$$

Thus, argumental values of snowfall depth for return periods of 50, 175, 200 and $1000 \mathrm{yr}$, are:

$$
\begin{aligned}
h_{T_{0=50}} & =0.661 \mathrm{~m} \\
h_{T_{0=175}} & =0.831 \mathrm{~m} \\
h_{T_{0=200}} & =0.849 \mathrm{~m} \\
h_{T_{0=1000}} & =1.067 \mathrm{~m}
\end{aligned}
$$

\section{Snow density}

The density of each yearly maximum snowfall depth was obtained from the water equivalent volume as recorded every $24 \mathrm{~h}$ in the rain gauge. Mean, standard deviation and coefficient of variation of the 207 new snow density values were:

$$
\begin{aligned}
\bar{\gamma} & =1.132 \mathrm{kN} \mathrm{m}^{-3} \\
\sigma_{\gamma} & =0.439 \mathrm{kN} \mathrm{m}^{-3} \\
C_{\gamma} & =0.388=38.8 \%
\end{aligned}
$$

In windy areas, $10 \%$ further doubt may be assumed, considering the underestimate associated with the measurement of snow water equivalent by normal rain gauges (Mercalli and Viarengo, 1989; Navarre, 1992).

The new snow density depends above all on air temperature and on the presence of wind during precipitation, while the density of snow cover on the ground tends to increase due to metamorphism phases during the accumulation of new snowfall (U.S. Department of Agriculture, 1980). At Turin (station at low altitude, $A=240 \mathrm{~m}$ ) the presence of snow cover is not continuous, but is characterized by one or more separated events, with intermittent snow layer on the ground, often for not longer than 10 consecutive days. In these conditions density variation in time may be neglected (Sanpaolesi and others, 1983) and a constant value may be taken for this parameter for specifically structural purposes. It is obvious that this value cannot be taken equal to the new snow density values (Equation (9)), 


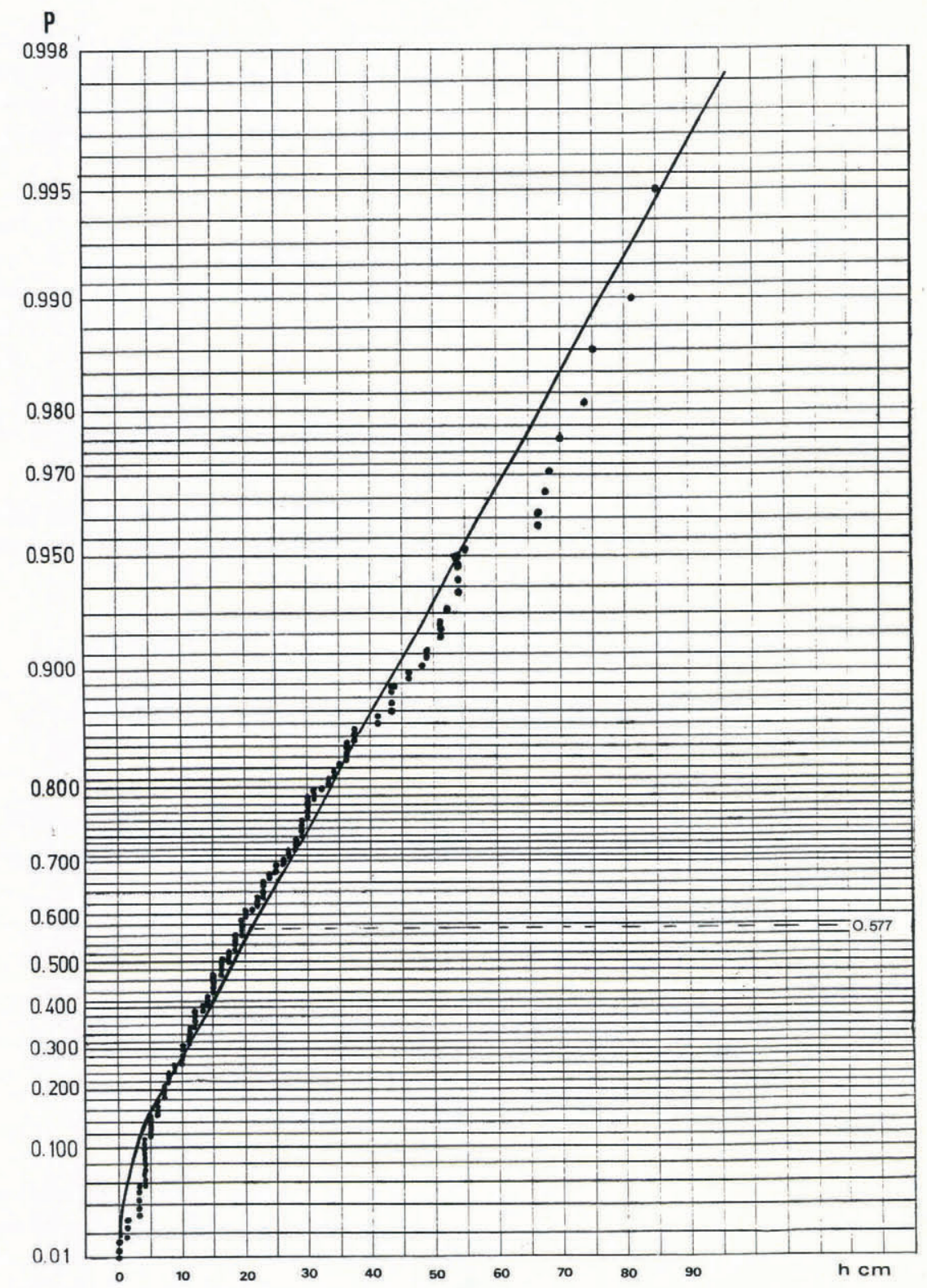

Fig. 5. Gumbel diagram. Distribution of yearly maximum new snowfall depths in Turin.

because it increases with continued snow precipitation, as evidenced by some researchers (Martinec, 1977), both experimentally and analytically. In particular, for snow some hours to days old, minimum values of density are $2.0 \mathrm{kN} \mathrm{m}^{-3}$ (Schweizer Norm. SIA 160, 1989; ISO/DIS $4355,1978)$.

\section{Snow load at the ground in Turin}

Yearly maximum snow loads on the ground, $q_{1}\left(\mathrm{kN} \mathrm{m}^{-2}\right)$ can be deduced from yearly maximum snowfall depths, $h_{1}(\mathrm{~m})$, following:

$$
q_{1}=2 h_{1}
$$

Assuming constant density the statistical distribution of the load on the ground is of the same kind as for snowfall depths. Statistical parameters of yearly maximum snow loads and argumental values combined with return periods generally conisdered in technical rules, appear in Table 6.

\section{Consideration of snow loads}

From Table 6 it appears that, on the basis of the analysis of this work the argumental value of snow load in Turin for a return period of $200 \mathrm{yr}$, is equal to $1.698 \mathrm{kN} \mathrm{m}^{-2}$. This is in good accord with Equation (3) which give a value of $1.720 \mathrm{kN} \mathrm{m}^{-2}$ for $A=240 \mathrm{~m}$.

Equation (2), properly extended to other areas of the country, also represents the Italian proposals for snowload technical rules to be included in the "Eurocode 1: Basis of design and actions on structures - Part 2.5: Snow loads".

\section{January 1987 snowstorm}

The period 1985 to 1987 included several heavy snowfalls in Turin, resulting in $112 \mathrm{~cm}$ of snowfall in the winter of 1985-86. This had not been reached since winter 1901-02 $(121 \mathrm{~cm})$. In winter 1986-87 snowfall amount reached $80 \mathrm{~cm}$. In 1986 precipitation was widely distributed in time, limiting damage only to the fall of snow from roofs. 
Average of yearly maximum snow loads

Standard deviation of yearly maxima

Coefficient of variation

Fractile 0.95 of yearly maxima distribution

Argumental value for return period $T_{0}=50 \mathrm{yr}$

Argumental value for return period $T_{0}=175 \mathrm{yr}$

Argumental value for return period $T_{0}=200 \mathrm{yr}$

Argumental value for return period $T_{0}=1000 \mathrm{yr}$

$\bar{q}_{1}$
$\sigma_{q_{1}}$
$c_{q_{1}}$
$\left(q_{1}\right)_{0.95}$
$q_{T_{0=50}}$
$q_{T_{0=175}}$
$q_{T_{0=200}}$
$q_{T_{0=1000}}$

$0.426 \mathrm{kN} \mathrm{m}^{-2}$

$0.346 \mathrm{kN} \mathrm{m}^{-2}$

$0.812=81.2 \%$

$1.072 \mathrm{kN} \mathrm{m}^{-2}$

$1.322 \mathrm{kN} \mathrm{m}^{-2}$

$1.662 \mathrm{kN} \mathrm{m}^{-2}$

$1.698 \mathrm{kN} \mathrm{m}^{-2}$

$2.134 \mathrm{kN} \mathrm{m}^{-2}$
In 1987 the greater intensity of snowfalls caused record structural breakages. In fact between 13 and 16 January, $67 \mathrm{~cm}$ of snow fell, the eighth highest amount in the series of maximum amounts since 1784. The highest, on 23 to 25 December 1808, was $85 \mathrm{~cm}$. The January 1987 snowstorm began at $0600 \mathrm{~h}(\mathrm{UTC}+1)$ on 13 January, due to the intervention of a warm front coming from the southwest, activated by a cyclonic area placed between Corsica and the Gulf of Genoa. The presence of a cold air layer on the Po plain (in Turin, $T_{\min }-7^{\circ} \mathrm{C}$ ) caused a light and dry snowfall till $1500 \mathrm{~h}$ on 14 January, when the snow depth was $30 \mathrm{~cm}$. Because of the continuous inflow of warm air from the Mediterranean Sea, the temperature approached $0^{\circ} \mathrm{C}$, with wet and heavy snow that at $2000 \mathrm{~h}$ became rain. During the night betwen 14 and 15 January the precipitation continued with a new amount of wet snow $(12 \mathrm{~cm})$ added to the depth on the ground $(36 \mathrm{~cm})$. In the evening of $15 \mathrm{January}$, temperature reached $+1{ }^{\circ} \mathrm{C}$ and precipitation became intermittent. The cyclonic circulation caused new wet snowfalls at the dawn of 16 January (temperature always near $0^{\circ} \mathrm{C}$ ). At 1800 h snow depth was $43 \mathrm{~cm}$, corresponding to a new snowfall amount of $67 \mathrm{~cm}$ and with water equivalent equal to $71.6 \mathrm{~mm}$ recorded (probably underestimated) by rain gauge. At $2200 \mathrm{~h}$ on 16 January the precipitation became rain, stopping in the night. During the same day most damage occurred. Tree branches broke in the town avenues, gutters and cornices caved in and plane roofs (in particular glass greenhouses, industrial sheds and steelworks sheltering fuel stations) collapsed. The damage caused by the snow sliding off roofs was enormous, with many parked cars damaged by wet snow masses.

\section{GONGLUSIONS}

Statistical analyses are carried out for the first time on the Turin daily snowfall series, one of the longest in Europe spanning over two centuries of continuous measurement. The time-series analysis of snowfall amount over the $200 \mathrm{yr}$ shows a decreasing trend, and allows detailed description of the characteristics of snow phenomenon in the Piedmont plain. This provides operational guidelines for the evaluation of the probability of events affecting many activities. For instance, the frequency of daily snowfall depths provides indications for public removal planning: in 95 cases out of a hundred the organisation will face daily snowfalls lower than $20 \mathrm{~cm}$; to take the extreme snowfalls of 1986 and 1987 as a model would overestimate the removal service with costs in the long periods of inactivity. On the other hand, the objective evaluation of the risk thresholds is decisive to size the works for which the safety limits must be strictly respected as in the case of structural loads analysed in this paper. Another field of interest is the estimate of the risk of late and early snowfalls with respect to agriculture. In October snowfalls can be considered exceptional. In April we may expect a snowfall every $11 \mathrm{yr}$.

\section{ACKNOWLEDGEMENTS}

This work results from five years of patient research and careful manuscript decoding carried out with the help of G. Di Napoli and L. Grinza. We are grateful to the Biblioteca dell'Accademia delle Science di Tórino and to Dr F. Dutto of Ufficio Idrografico del Po di Tórino, for allowing us to consult their archives.

\section{REFERENCES}

Beraudo, G. D. 1785. Stato della straordinaria nevicazione dell'inverno 178485 registrata dall'osservatore Beraudi (sic) nella $R$. Città di Tórino. Tórino, private collection.

Biancotti, A., G. Brancucci, L. Massaglia and L. Mercalli. 1991. La serie termopluviometrica di Cuneo 1877-1990. Studi e Ricerche di Geografia, $14(2), 214223$.

Biasoli, F. and E. Leporati. 1983. L'azione della neve in Piemonte e nella Valle d'Aosta. Risultati di un'indagine statistica. Politecnico di Tórino. Atti Ist. Sci. Costr. 597.

Brizio, D. and L. Mercalli. 1992. Pioggia e neve a Bra; 130 anni di osservazioni (1862-1991). Città di Bra, Museo Civico Craveri.

Giuffrida, A. and M. Conte. 1989. Variations climatiques en Italie: tendences des températures et des précipitations. In Association Internationale de Climatologie, Colloque de Pavie, Aix-en-Provence, 209-216.

International Organization for Standardization. 1978. Bases du calcul des constructions. Détermination de la charge de neige sur les toitures. Geneva, International Organization for Standardization. (No. 4355.)

Leporati, E. 1983. L'azione della neve sulle strutture. Il modello probabilistico. Politecnico di Torino. Atti Ist. Sci. Costr. 590.

Martinec, J. 1977. Expected snow loads on structures from incomplete hydrological data. J. Glaciol., 19 (81), 185-195. 
Mercalli, L. and S. Viarengo. 1989. Problèmes posés par la mesure de l'équivalent en eau de la neige par des pluviographes chauffés. In Association Internationale de Climatologie, Colloque de Pavie, Aix-en-Provence. Vol. 2, 111-114.

Ministero dei Lavori Pubblici. 1982a. Istruzioni relative ai carichi, ai sovraccarichi ed ai criteri generali per la verifica della sicurezza delle construzioni. Roma, Ministero dei Lavori Pubblici. (Circolare Ministeriale LL.PP. 24.05.1982, No. 22631.)

Ministero dei Lavori Pubblici. 1982b. Norme tecniche relative ai criteri generali per la verifica di sicurezza delle costruzioni. Roma, Ministero dei Lavori Pubblici (Decreto Ministeriale 12.02.1982.)

Navarre, J. P. 1992. La neige et les constructions. Les surcharges et leurs conséquences, l'épisode du 8-13 décembre 90 dans Rhône-Alpes. Neige et Avalanches 58, 3-7.

Rebaudengo, D. 1969. Torino racconta. Tórino.

Regione del Veneto. Dipartimento Foreste. 1980. Manuale delle valanghe. [U.S. Department of Agriculture. Forest Service. Avalanche handbook, 1953.] Edizione ilaliana a cura di M. Crespi. Venezia, Regione del Veneto. Dipartimento Foreste. Centro Sperimentale Valanghe e Difesa Idrogeologica.

Rossetti, D. 1681. La figura della neve. Tórino, Biblioteca Civica.
Sanpaolesi, L. R. del Corso and S. Ligarò. 1983. Analisi statistica dei valori del carico di riferimento da neve al suolo in Italia. G. Genio Civ., $1983,7-8-9,265-278$.

Società Svizzera degli Ingegneri e Architetti. 1989. Azioni sulle strutture portanti. Zürich, Società Svizzera degli Ingegneri e Architetti. (Schweizer Norm. SIA 160.)

Vassalli-Eandi, A. M. 1806. Saggio del nuovo sistema metrico col rapporto delle nuove misure alle antiche misure francesi e a quelle del Piemonte. Tórino, Impr. Pomba.

Vassalli-Eandi, A. M. 1808. Résultats des observations météorologiques faites à l'Observatoire de l'Académie de Turin depuis le $I^{\text {er }}$ janvier 1787 jusqu'au même jour du 1807. Tórino, Impr. de l'Académie.

Vassalli-Eandi, A. M. 1810. Annales de l'Observatoire de l'Académie de Turin avec des notices statistiques concernant l'agriculture et la médecine. Tórino, Impr. Sociale.

The accuracy of references in the text and in this list is the responsibility of the authors, to whom queries should be addressed. 